Jurnal Keperawatan Hang Tuah (Hang Tuah Nursing
Journal)
e-ISSN 0000-0000

\title{
TINGKAT KEPUASAN PASIEN PENYAKIT KRONIS TERHADAP PEMENUHAN KEBUTUHAN SPIRITUAL SELAMA DIRAWAT DI RSUD ARIFIN ACHMAD PROVINSI RIAU
}

\author{
Gesni Mehika', Bayhakki ${ }^{2}$, Rani Lisa Indra ${ }^{3}$ \\ ${ }^{1,3}$ Program Studi Keperawatan STIKes Hang Tuah Pekanbaru \\ ${ }^{2}$ Fakultas Keperawatan Universitas Riau
}

Email: 1 mehikot@gmail.com

\section{Histori artikel}

Received:

09 Desember 2020

Accepted:

15 Februari 2021

Published:

16 Februari 2021

\begin{abstract}
Abstrak
Penyakit kronis merupakan gejala penyakit yang dirasakan dalam jangka waktu lebih dari enam bulan. Saat seseorang menderita penyakit kronis, aspek spiritual merupakan salah satu keadaan yang akan dipengaruhi. Tujuan dari penelitian ini adalah untuk mengetahui tingkat kepuasan pasien penyakit kronis terhadap pemenuhan kebutuhan spiritual selama dirawat di rumah sakit. Penelitian ini adalah jenis penelitian kuantitatif dengan metode deskriptif dan desain cross sectional. Jumlah sampel penelitian ini adalah 63 orang pasien dengan menggunakan teknik consecutive sampling. Analisis data yang digunakan adalah analisis univariat, dan hasil menunjukkan 39,7\% pasien berusia dalama kategori dewasa akhir, 58,7\% bejenis kelamin perempuan, 47,6\% responden tidak bekerja, 49,2\% responden merupakan tamatan SMA, 90,5\% responden berstatus kawin dan 36,5\% responden didiagnosa menderita kanker payudara. Kepuasan pasien terhadap pemenuhan kebututhan spiritual diperoleh hasil 69,8\% pasien merasa tidak puas, sebagian besar responden memiliki tingkat
\end{abstract}


kepuasan yang rendah terhadap pemenuhan kebutuhan mempertahankan hubungan baik dan pelaksanaan praktik ibadah. Berdasarkan hasil penelitian ini diharapkan institusi pendidikan dan tempat penelitian dapat mempersiapkan perawat yang sehat secara spiritual agar mampu melaksanakan pemenuhan kebutuhan spiritual secara optimal kepada pasien dan mampu meningkatkan mutu pelayanan keperawatan.

Kata-kata Kunci Kepuasan pasien, Penyakit kronis, Spiritual.

\begin{abstract}
Chronic disease is a condition of disease lasts for more than six months. If a person have chronic condition, the one of spiritual aspect to be affected. The purpose of this research to know the satisfaction of spiritual needs fulfillment with patient chronic disease on hospitalization. This was a quantitative study with descriptive and cross sectional design. The sample were 63 which taken by consecutive sampling. The data analyze were univariate, the result showed that $39,7 \%$ patient were in the late-age adult, 58,7\% patient were female, $47,6 \%$ patient were unemployment, 49,2\% patient were high school graduates, 90,5\% patient were merried and $69,8 \%$ patient were breast cancer of diagnosed. The satisfaction of spiritual needs fulfillment were 69,8\% not satisfied of patient, the majority of patient were not satisfied with maintain good relations and religious practices of fulfillment. The results of this study is expected to educational institutions and research sites to prepare healthy nurses spiritually in order to be able to carry out the fulfillment of spiritual needs optimally to patients and able to improve the quality of nursing services.

\section{Kata-kata Kunci Chronic diseases, Satisfaction of Patient, Spiritual.}

\title{
PENDAHULUAN
}

Penyakit kronis merupakan gejala penyakit yang dirasakan dalam jangka waktu lebih dari enam bulan dan menyebabkan perubahan fungsi biologis, psikologis, sosio-kultral dan spiritual (Dewi, 2014). Saat seseorang menderita penyakit kronis, aspek spiritual merupakan salah satu keadaan yang akan dipengaruhi. Perawat sebagai tenaga kesehatan yang profesional yang memiliki kemampuan intelektual, interpersonal, moral, bertanggung jawab, 
membantu menyelesaikan masalah kesehatan pasien selama 24 jam secara terus menerus. (Asmadi, 2008; Abuatiq, 2015).

Praktik asuhan keperawatan, perawat sering merasa didorong untuk fokus pada perawatan fisik pasien sehingga mengorbankan perawatan emosional dan spiritual. Berbagai faktor yang menyebabkan perawat menghindar untuk memberikan asuhan spiritual. Alasan seperti perawat merasa kurang nyaman dengan kehidupan spiritualnya, kurang menganggap penting kebutuhan spiritual, tidak mendapatkan pendidikan tentang aspek spiritual dalam keperawatan, atau marasa bahwa pemenuhan kebutuhan spiritual pasien bukan menjadi tugasnya, tetapi tanggung jawab pemuka agama (Hamid, 2009; Baldacchino, 2015; Noor, 2016).

Intervensi sederhana seperti duduk bersama pasien sambil berkomunikasi, mendengarkan keluhan, memberi semangat, memberikan kebutuhan informasi dan kebutuhan fisik, membantu menentukan makna hidup, serta membuat rujukan yang tepat merupakan contoh pemenuhan kebutuhan spiritual pasien dalam proses penyembuhan (Abuatiq, 2015; Baldecchino, 2015).

Selama 20 abad, lebih dari 200 studi telah meneliti hubungan antara keyakinan agama dan kesehatan. Mayoritas menemukan hubungan yang positif antara hasil perawatan kesehatan dan spiritual (Bennet \& Tompson, 2015). Perawatan kesehatan yang berkaitan dengan kebutuhan spiritual akan memberikan kontribusi yang positif untuk perbaikan atau pemulihan pasien. Hasil analisis regresi dalam European Journal of Medical Research (2010) menunjukkan hubungan yang kuat antara kondisi penyakit kronis dengan kebutuhan spiritual. Berdasarkan hasil observasi pada 22 Maret 2017 di RSUD Arifin Achmad, aspek spiritual belum mendapatkan perhatian yang cukup oleh perawat dan belum sesuai dengan yang diharapkan. Hal ini dibuktikan dengan sedikitnya perawat yang membantu memfasilitasi dan menanyakan semua hal yang berkaitan dengan kebutuhan spiritual. Sementara hasil wawancara terhadap lima orang pasien, seluruhnya mengatakan bahwa mereka ingin kebutuhan spiritual terpenuhi saat sehat atau sakit. Mereka percaya bahwa keadaan sakit merupakan salah satu cara Allah untuk menghapus dosa hamba-Nya.

Selain itu, tiga dari lima orang pasien mengungkapkan bahwa beberapa perawat berperilaku tidak seperti yang diharapkan. Tidak semua perawat memberikan penjelasaan terkait penyakit yang diderita oleh pasien. Ketika pasien bertanya tentang kondisi kesehatannya, pasien merasa tidak puas dengan jawaban yang diberikan oleh perawat sehingga menimbulkan kegelisahan atau kecemasan dan rasa tidak berharga pada diri pasien. Dua pasien yang diwawancarai juga mengeluhkan rasa tidak nyaman untuk melaksanakan ibadah di ruang rawat inap karena suasana yang tidak kondusif. parawat seharusnya memberikan asuhan 
keperawatan secara komprehensif dan holistik kepada pasien untuk mencapai keadaan sehat yang optimal. Tujuan penelitian ini adalah untuk mendeskripsikan pemenuhan kebutuhan spiritual pada pasien penyakit kronis selama dirawat di rumah sakit.

\section{METODELOGI PENELITIAN}

Jenis penelitian ini adalah kuantitatif deskriptif dengan pendekatan cross sectional. Populasi yang dimaksud dalam penelitian ini adalah seluruh penderita penyakit kronis yang dirawat di RSUD Arifin Achamd tahun 2017 yakni sebanyak 315 orang. Sampel pada penelitian ini adalah pasien penderita penyakit kronis yang memiliki TTV dalam rentang normal, berusia $\geq 25$ tahun, beragama islam, dan sudah dirawat dirumah sakit minimal selama 3 hari. Pengambilan sampel pada penelitian ini menggunakan teknik consecutive sampling dengan alat pengumpulan data menggunakan lembar kuesioner.

\section{HASIL PENELITIAN}

Hasil penelitian yang dilakukan dari bulan juli sampai bulan agustus 2017 pada 63 responden pasien penyakit kronis yang dirawat di RSUD Arifin Achmad, dengan data yang diperoleh sebagai berikut.

\section{A. Karakteristik Responden}

Tabel 1. Distribusi frekuensi umur, jenis kelamin, pekerjaan, pendidikan terakhir, dan status pernikahan.

\begin{tabular}{|c|c|c|c|}
\hline No & Karakteristik responden & $\mathrm{N}$ & $\%$ \\
\hline \multirow[t]{5}{*}{1} & Umur & & \\
\hline & Dewasa awal (25-35) & 12 & 19,0 \\
\hline & Dewasa madya (36-45) & 17 & 27,0 \\
\hline & Dewasa akhir (46-60) & 25 & 39,7 \\
\hline & Lansia (>61) & 9 & 14,3 \\
\hline \multirow[t]{3}{*}{2} & Jenis kelamin & & \\
\hline & Laki-laki & 26 & 41,3 \\
\hline & Perempuan & 37 & 58,7 \\
\hline \multirow[t]{6}{*}{3} & Pekerjaan & & \\
\hline & Pedagang & 11 & 17,5 \\
\hline & Petani & 10 & 15,9 \\
\hline & Swasta & 10 & 15,9 \\
\hline & Buruh & 2 & 3,2 \\
\hline & Tidka bekerja & 30 & 47,6 \\
\hline \multirow[t]{6}{*}{4} & Pendidikan terakhir & & \\
\hline & SD & 7 & 11,1 \\
\hline & SMP & 17 & 27,0 \\
\hline & SMA & 31 & 49,2 \\
\hline & Sarjana & 6 & 9,5 \\
\hline & Tidak sekolah & 2 & 3,2 \\
\hline
\end{tabular}




\begin{tabular}{llcc}
\hline 5 & Status perkawinan & & \\
& Kawin & 57 & 90,5 \\
& Belum kawin & 2 & 3,2 \\
& Janda & 3 & 4,8 \\
& Duda & 1 & 1,6 \\
\hline 6 & Jenis penyakit & \\
CHF & 3 & 4,8 \\
& DM & 4 & 6,3 \\
GGK & 2 & 3,2 \\
HHD & 3 & 4,8 \\
Jantung Koroner & 2 & 3,2 \\
Jantung Rematik & 1 & 1,6 \\
Kanker kolon & 1 & 1,6 \\
Kanker buli-buli & 1 & 1,6 \\
Kanker kelenjar getah bening & 2 & 3,2 \\
Kanker laring & 1 & 1,6 \\
Kanker nasoparing & 1 & 1,6 \\
Kanker payudara & 23 & 36,5 \\
Kanker tiroid & 1 & 1,6 \\
Kannker tulang & 1 & 1,6 \\
Kanker servik & 5 & 7,9 \\
Meningitis & 1 & 1,6 \\
Otitis media kronik & 1 & 1,6 \\
PPOK & 3 & 4,8 \\
Serosis hepatis & 2 & 3,2 \\
Strok & 2 & 3,2 \\
TB paru resisten & 2 & 3,2 \\
Unstabel angina pectoris & 1 & 1,6 \\
\hline Total & 63 & 100 \\
\hline
\end{tabular}

Berdasarkan hasil analisis pada tabel 1 dapat disimpulkan bahwa sebagian besar pasien penyakit kronis berusia dewasa akhir yaitu berjumlah 25 orang (39,7\%). Mayoritas pasien adalah perempuan dengan jumlah 37 orang (58,7\%). Berdasarkan kareakteristik pendidikan terakhir sebagian besar pasien adalah tamatan SMA dengan jumlah 31 orang (49,2\%). Status pekerjaan mayoritas pasien adalah tidak bekerja dengan jumlah 30 orang (47,6\%). Sebagian besar pasien sudah menikah dengan jumlah 57 orang (90,5\%). Berdasarkan jenis penyakit yang diderita oleh mayoritas pasien adalah penyakit kanker payudara dengan jumlah 23 orang $(36,5 \%)$.

B. Tingkat kepuasan pasien terhadap pemenuhan kebutuhan spiritual

Tabel 2. Distribusi frekuensi tingkat kepuasan pasien penyakit kronis terhadap pemenuhan kebutuhan spiritual 
Tingkat kepuasan
Frekuensi (f)

Persentase (\%)

\begin{tabular}{lcc}
\hline Puas & 19 & 30,2 \\
\hline Tidak puas & 44 & 69,8 \\
\hline Total & 63 & 100 \\
\hline
\end{tabular}

Berdasarkan tabel 2 diketahui bahwa tingkat kepuasan pasien penyakit kronis terhadap pemenuhann kebutuhan spiritual selama dirawat di rumah sakit pada kategori tidak puas dengan jumlah 44 responden $(69,8 \%)$.

\section{PEMBAHASAN}

A. Karakteristik responden

1. Usia

Berdasarkan data dari hasil penelitian yang telah dilakukan pada pasien rawat inap menunjukkan paling banyak responden dengan golongan usia dewasa akhir (46-60) yaitu berjumlah 25 orang (37,9\%). Hal ini didukung oleh pernyataan yang menyatakan bahwa semakin bertambahnya usia, beberapa kemampuan fisiologis ikut menurun dan biasanya dimulai pada usia 45 tahun (Efendi \& Makhfudli, 2009).

Penelitian yang telah dilakukan oleh Stefan, Redjeki \& Susilo (2013) diketahui bahwa tidak ada hubungan yang bermakna antara umur dengan kepuasan pasien terhadap mutu pelayanan kesehatan. Hal ini juga didukung dengan hasil penelitian yang dilakukan oleh Oroh, Rompas \& Pondang (2014) juga mengatakan bahwa tidak ada hubungan yang bermakna antara umur dengan tingkat kepuasan pasien rawat inap.

Setiap individu memiliki penilaian dan pola pikir yang berbeda terhadap suatu jasa yang diberikan. Kepuasan sangat bersifat subjektif karena setiap individu akan memiliki sudut pandang yang berbeda. Hal ini didukung dengan hasil penelitian yang dilakukan oleh Setiawan \& Kariasa (2013) yang memperoleh hasil berdasarkan karakteristik umur didapatkan gambaran bahwa tingkat kepuasannya berbeda-beda. Hal ini disebabkan karena harapan dari seseorang dipengaruhi oleh banyak faktor seperti pertumbuhan, perkembangan, pengalaman dan lain-lain.

Berdasarkan hal tersebut penelliti menyimpulkan bahwa ketika individu mengalami pertambahan usia maka peluang untuk terjadinya penyakit akan semakin bertambah, 
sehingga tidak menutup kemungkinan semua golongan usia akan mengalami kondisi kronis. Selain itu, semakin bertambah usia maka akan memengaruhi pola hidup dan pengalaman yang tercermin dalam kebiasaan hidup seseorang sehingga akan berdampak pada tingkat kepuasan seseorang.

2. Jenis kelamin

Jenis kelamin adalah perbedaan bentuk, sifat, dan fungsi biologi laki-laki dan perempuan yang menentukan perbedaan peran mereka dalam menyelenggarakan upaya meneruskan garis keturunan. Perbedaan ini terjadi karena meraka memiliki alat-alat untuk meneruskan keturunan yang berbeda, yaitu disebutalat reproduksi (Prasetiyo, 2015).

Pengolahan data menunjukkan bahwa distribusi responden menurut jenis kelamin, pasien rawat inap menunjukkan paling banyak responden dengan jenis kelamin perempuan yaitu sebesar 37 orang (58,7\%) dibandingkan dengan pasien laki-laki yaitu sebanyak 26 orang (41,3\%). Hasil penelitian ini sama dengan Oroh, Rompas \& Pondang (2014) dengan penelitian pada pasien rawat inap di RSUD Noongan dimana sebagian besar adalah responden perempuan (53\%).

Jika dilihat data dari National Survei Wawancara Kesehatan 2009-2010, Persentase orang dewasa dengan dua atau lebih kondisi kronis meningkat untuk pria dan wanita. Pada 2009-2010, 21\% orang dewasa berusia 45-64 tahun dan 45\% orang dewasa berusia $\geq 65$ tahun telah didiagnosis dengan dua atau lebih kondisi kronis (CDC, 2012).

Berdasarkan hasil penelitian yang dilakukan oleh Abdilah \& Ramdan (2006) yang menunjukkan bahwa faktor jenis kelamin tidak menujukkan ada hubungan yang signifikan dengan kepuasan pasien. Hal ini juga sama dengan hasil yang diperoleh yang menunjukkan bahwa tidak terdapat hubunggan antara jenis kelamin dengan kepuasan pasien. Wanita cenderung memiliki kepribadian yang lemah dan perasaan yang sensitif terhadap suatu perlakuan yang diberikan oleh seseorang kepadanya. Hal ini didukung dengan hasil penelitian yang dilakukan oleh Setiawan \& Kariasa (2013) yang menyatakan bahwa gambaran tingkat kepuasan antara laki-laki dan perempuan berbeda.

Berdasarkan hasil penelitian yang telah dilakukan diketahui bahwa penderita penyakit kronis mayoritas pasien berjenis kelamin perempuan, hal ini kemungkinan disebabkan oleh jenis penyakit yang diderita kebanyakan pasien dalam penelitian ini adalah kanker payudara yang sering menyerang perempuan. Sehingga peneliti menyimpulkan bahwa laki-laki dan perempuan sama-sama memiliki peluang untuk mengalami sakit namun memiliki konsep diri yang berbeda sehingga akan berpengaruh pada penilaian dan tingkat kepuasan seseorang terhadap suatu jasa atau pelayanan kesehatan yang di terima.

3. Pekerjaan 
Pekerjaan secara umum didefinisikan sebagai sebuah kegiatan aktif yang dilakukan oleh manusia. Dalam arti sempit, istilah pekerjaan digunakan untuk suatu tugas atau kerja yang menghasilkan sebuah karya bernilai imbalan dalam bentuk uang bagi seseorang (Prasetiyo, 2015). Berdasarkan hasil penelitian karakteristik responden berdasarkan pekerjaan, diperoleh hasil responden yang tidak bekerja memiliki persentase tertinggi yaitu 47,6\%. Hasil penelitian yang dilakukan oleh Farianita (2016) diketahui bahwa tidak terdapat hubungan antara status pekerjaan dengan kepuasan terhadap pelayanan.

Namun hal ini berbeda hasil penelitian yang dilakukan oleh Stefan (2013), responden yang bekerja pada umumnya memiliki banyak tuntutan dan harapan akan pelayanan kesehatan yang dibutuhkan, pelayanan yang diberikan harus sejalan dengan biaya yang dikeluarkan. Responden yang tidak bekerja pada umumnya tidak memiliki tuntutan dan harapan yang tinggi terhadap pelayanan kesehatan, selama dapat kembali sembuh dengan pelayanan kesehatan yang diberikan pasien akan kembali untuk berobat di tempat tersebut. Berdasarkan hal tersebut, peneliti menyimpulkan bahwa status pekerjaan seseorang akan mempengaruhi penilaian dan tingkat kepuasan individu, tetapi tidak menutup kemungkinan bagi orang yang tidak bekerja juga memiliki penilaian yang sama dengan orang yang memiliki pekerjaan.

\section{Pendidikan}

Berdasarkan hasil penelitian karakteristik responden berdasarkan distribusi frekuensi tertinggi, tingkat pendidikan terakhir yang dimiliki oleh responden adalah tamatan SMA dengan jumlah 31 orang $(49,2 \%)$. Pendidikan memiliki potensi untuk mengubah keyakinan dan perilaku kesehatan dan tingkat pendidikan masih memberikan sumbangan yang kuat dalam mencari pekerjaan yang berdampak pada sistem sosial. Pendidikan erat kaitannya dengan pekerjaan yang berdampak pada ekonomi atau penghasilan seseorang dan berpengaruh pada status kesehatan (Feinstein, Sabates, Anderson, Sorhaindo \& Hammond, 2006).

Hasil penelitian yang dilakukan oleh Stefan, Redjeki \& Susilo (2013) menunjukkan bahwa terdapat hubungan yang bermakna antara pendidikan dengan kepuasan pasien terhadap mutu pelayanan kesehatan. Responden yang berpendidikan tinggi cenderung merasa kurang puas terhadap pelayanan kesehatan yang diberikan oleh petugas kesehatan dibandingkan dengan responden yang berpendidikan rendah. Semakin tinggi pendidikan seseorang akan membuat seseorang semakin mengerti akan arti kesehatannya, sehingga menyebabkan semakin banyak tuntutan dan harapannya akan pelayanan kesehatan yang dibutuhkan.

Hasil penelitian yang dilakukan Setiawan \& Kariasa (2013) juga memperoleh hasil yang sama bahwa berdasarkan tingkat pendidikan didapatkan bahwa kepuasan pada individu yang 
berpendidikan berbeda-beda. Hal ini disebabkan karena individu yang memiliki pendidikan tinggi akan memiliki pola pikir yang lebih kritis, informatif, dan memiliki harapan yang lebih sehingga cenderung merasa tidak cukup puas dengan pelayanan yang kurang sesuai dengan harapan. Sedangkan individu yang memiliki pendidikan rendah cenderung menerima pelayanan yang telah diberikan (Farianita, 2016). Sehingga dapat disimpulkan bahwa ilmu yang dimiliki seseorang akan memberikan pengaruh yang besar terhadap kehidupan seseorang. Baik dalam berperilaku, berfikir, menilai dan mengambil keputusan.

5. Status perkawinan

Jika seseorang menikah, maka ia telah menyempurnakan separuh agamanya. Karenanya bertakwalah kepada Allah pada separuh yang lainnya. Menikah akan membuat seseorang lebih merasakan ketenangan. Telah dijelaskan oleh Allah dalam QS.Ar-Ruum;21 .

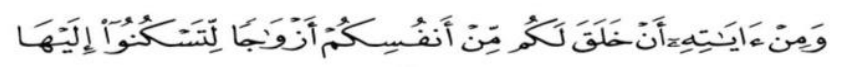

Artinya:"Dan diantara tanda-tanda kekuasaan-Nya ialah Dia menciptakan untukmu isteri-isteri dari jenismu sendiri, supaya kamu cenderung dan merasa tentram kepadanya".

Hal ini berarti bahwa, dengan menikah akan lebih menentramkan jiwa karena adanya pendamping. Seseorang akan merasa tenang ketika berada di samping pasangannya karena Allah telah memberikan didalam pernikahan terdapat ketentraman yang tidak dapat digantikan dengan yang lainnya. Berdasarkan hasil penelitian diperoleh hasil bahwa sebagian besar penderita penyakit kronis telah menikah $(90,5 \%)$.

Menikah salah satu upaya dalam mengatur perilaku kesehatan individu atau kontrol sosial terkait kesehatan adalah hubungan sosial. Hasil penelitian diperoleh bahwa individu yang sudah menikah menunjukkan respon perilaku, emosional yang positif. Selain itu, individu yang telah menikah bisa menjadikan pasangan sebagai sumber kontrol sosial yang positif sehingga pentingnya status perkawinan dan perbedaan gender dalam keterlibatan jaringan sosial dalam pengelolaan penyakit kronis (August \& Sorkin, 2010).

6. Jenis penyakit

Hidup ini tidak lepas dari cobaan dan ujian, bahkan cobaan dan ujian merupakan Sunatullah dalam kehidupan. Manusia akan diuji dalam kehidupannya baik dalam perkara yang tidak disukai atau pada perkara yang menyenangkan. Ibnu 'Abbas yang menafsirkan QS. Al-Anbiya; 35 yang artinya, kami akan menguji kalian dengan kesulitan dan kesenangan, kesehatan dan penyakit, kekayaan dan kefakiran, halal dan haram, ketaatan dan kemaksiatan, petunjuk dan kesesatan. Dari ayat ini dapat diketahui bahwa berbagai macam penyakit juga merupakan bagian dari cobaan Allah yang diberikan kepada hamba-Nya. Namun dibalik cobaan ini, terdapat berbagai rahasia dan hikmah yang tidak dapat dinalar oleh akal manusia. Survei Wawancara Kesehatan Nasional (NHIS) melaporkan bahwa selama periode 10 tahun 
terakhir penyakit kronis yang sering dialami oleh populasi usia $\geq 45$ tahun adalah hipertensi, penyakit jantung, diabetes, kanker, stroke, bronkitis kronis, emfisema, asma, dan penyakit ginjal (CDC, 2012).

Berdasarkan hasil penelitian diperoleh hasil persentase jenis penyakit kronis yang diderita oleh responden adalah penyakit kanker payudara dengan jumlah 23 orang (35,6\%). Hal ini didukung dengan pernyataan dalam Pusat Data dan Informasi (2015) yang mengatakan bahwa penyakit kanker menrupakan penyebab kematian utama diseluruh dunia. Prevalensi penderita kanker pada penduduk semau umur di Indonesia sebesar 1,4\%. Kanker payudara memiliki angka kejadian pada tahun 2013 sebanyak 0,3\% atau berjumlah 894 orang di Provinsi Riau (Pusat Data dan Informasi Kesehatan, 2015).

Dari uraian beberapa hasil penelitian diatas, banyak faktor yang menyebabkan seseorang mengalami sakit. Namun, jika dikembalikan kepada konsep spiritual yang harus kita renungi adalah apapun jenis penyakit yang dialami seseorang sudah merupakan ketetapan dari Allah dan merupakan akibat dari perilaku hidup, dosa atau maksiat yang telah dilakukan oleh individu itu sendiri. Hal ini telah disebutkan dalam QS. Asy-Syura: 30.

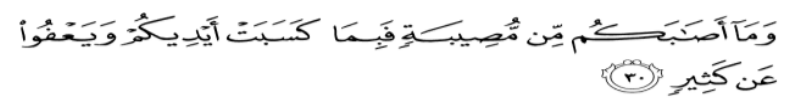

Artinya: “ Dan apa saja musibah yang menimpa kamu maka adalah disebabkan oleh perbutan tanganmu sendiri dan Allah memaafkan sebagian besar (dari kesalahan-kesalahanmu)".

B. Tingkat kepuasan pasien terhadap pemenuhan kebutuhan spiritual Kepuasan pasien merupakan respon dari terpenuhnya kebutuhan sesuai dengan apa yang diharapkan pasien. Pasien akan puas apabila pelayanan kesehatan yang diterima atau yang diberikan melebihi harapannya dan sebaliknya pasien merasa tidak puas atau kecewa apabila pelayanan kesehatan yang diterimanya tidak sesuai harapannya (Pohan, 2007).

Hasil penelitian yang dilaksanakan oleh Ilhamsyah, sjattar \& Hadju (2013) diperoleh hasil adanya hubungan yang bermakna antara pelaksanaan keperawatan spirirtual dengan kepuasan spirirtual pasien. Kualitas pelayanan yang baik, sangat mempengaruhi kepuasan pasien selama dirawat. Hal ini menjelaskan bahwa kualitas pelayanan yang diberikan oleh pihak rumah sakit akan memberikan pengaruh yang besar bagi kepuasan pasien, sehingga untuk memberikan kepusaan bagi pasiennya, setiap rumah sakit harus memberikan pelayanan yang memuaskan.

Pemberian dukungan spiritual merupakan salah satu peran perawat dalam pelayanan asuhan keperawatan. Perawat harus berupaya membantu memenuhi kebutuhan spiritual klien 
sebagai bagian dari kebutuhan menyeluruh klien. Dukungan spiritualitas yang diberikan perawat dalam pemenuhan kebutuhan spiritual akan meningkatkan spiritualitas pasien (Hamid, 2008).

Berdasarkan hasil penelitian ini, terdapat empat item dukungan spirirtual perawat. Item tersebut yaitu dukungan dalam pemenuhan praktik ibadah dan mempertahankan hubungan baik kepada Allah, menemukan makana, harapan dan tujuan hidup, memepertahankan hubungan yang baik dan memperoleh dukungan.

Hasil penelitian diperoleh diketahui tingkat kepuasan pasien penyakit kronis terhadap pemenuhan kebutuhan spiritual selama dirawat inap di rumah sakit diketahui bahwa sebagian besar pasien merasa tidak puas $(69,8 \%)$. Hasil penelitan ini didukung dengan hasil penelitian yang dilakukan oleh Lestari \& Safuni (2015) yang memperoleh hasil 51,4\% pemenuhan kebutuhan spiritual pasien pada kategori kurang baik dan $48,6 \%$ pada kategori baik.

Hasil penelitian yang dilakukan oleh Sumarni, Dewi \& Arneliwati (2016) tentang analisis asuhan keperawatan spiritualitas pada pasien kanker payudara di RSUD Arifin Achmad diketahui bahwa perawat yang melaksanakan pengkajian berjumlah 4 orang (20\%) dan 16 orang (80\%) kurang melaksanakan, membuat diagnosa keperawatan sebanyak 2 orang (10\%) dan 18 orang $(90 \%)$ belum membuat diagnosa keperawatan, rencana keperawatan belum terlaksana, tindakan keperawatan 4 orang (20\%) sudah melaksanakan dan 16 orang $(80 \%)$ kurang melaksanakan, pada evaluasi 1 orang (5\%) sudah melaksanakan dan 19 orang (95\%) kurang melaksanakan.

Mengetahui keberhasilan tindakan dan untuk mencapai kesehatan spiritual yang optimal dengan penanganan yang tepat dibutuhkan data yang akurat, semua data terkait masalah dan kebutuhan pasien telah teridentifikasi dan terdokumentasi menjadi satu kesatuan dalam rencana asuhan keperawatan. Sehingga penting untuk melakukan pengkajian, diagnosa, rencana intervensi, implementasi dan evaluasi serta dokumtasi terkait aspek spiritual karena masalah spirirtual antara pasien yang satu berbeda dengan pasien yang lain.

Hasil penelitian ini juga didukung dengan pernyataan yang mengatakan bahwa terdapat berbagai faktor yang menyebabkan perawat menghindar untuk memberikan asuhan spiritual. Alasan seperti perawat merasa kurang nyaman dengan kehidupan spiritualnya, kurang menganggap penting kebutuhan spiritual, tidak mendapatkan pendidikan tentang aspek spiritual dalam keperawatan, atau marasa bahwa pemenuhan kebutuhan spiritual pasien bukan menjadi tugasnya, tetapi tanggung jawab pemuka agama (Hamid, 2009; Baldacchino, 2015; Noor, 2016). Hasil penelitian yang dilakukan oleh Wahyuni, Hartiti \& Samiasih (2013) juga mengatakan bahwa pengetahuan perawat tentang kebutuhan spiritual pasien yaitu $52,6 \%$ dalam kategori rendah. 
Penelitian lain yang dilakukan oleh Bussing dan Koening (2010) diketahui bahwa pasien menyatakan perawatan spiritual sering tidak tercukupi dan responden ingin kebutuhan spiritualnya terpenuhi. Ada beberapa faktor yang memengaruhi praktik asuhan keperawatan spiritual, seperti perawat merasa didorong untuk fokus pada perawatan fisik pasien sehingga mengorbankan perawatan emosional dan spiritual (Hamid, 2009; Baldacchino, 2015; Noor, 2016).

Berdasarkan hasil penelitian dan analisis peneliti menunjukkan bahwa pasien penyakit kronis merasa tidak puas dengan pemenuhan kebutuhan spiritual selama dirawat di rumah sakit. Hal ini kemungkinan disebabkan oleh banyak faktor yang mempengaruhi tingkat kepuasan mengenai aspek spiritual, seperti kualitas keimanan kepada Allah, kualitas ilmu, konsep diri dan mekanisme koping yang dimiliki. Pernyataan ini didukung dengan teori yang mengatakan bahwa spiritual merupakan konsep komplek yang unik dan multidimensi pada tiap individu yang bergantung pada perkembangan, pengalaman hidup, kepercayaan dan ide-ide tentang kehidupan seseorang (Potter \& Perry, 2010; Rajinikanth, 2006; Hamid, 2009).

Berdasarkan hal tersebut dapat ditarik kesimpulan bahwa banyak faktor yang menyebabkan pemenuhan kebutuhan spirtitual belum terlaksana secara optimal. Salah satu faktor yang perlu dipertimbangkan adalah kurangnya pembaharuan informasi tentang keperawatan spiritual bagi pemberi pelayanan kesehatan. Jumlah tenaga kesehatan yang belum sebanding dengan jumlah pasien yang dirawat dan beban kerja setiap tenaga kesehatan juga perlu menjadi bahan pertimbangan, karena hal ini akan berdampak pada kinerja perawat yang kurang optimal dalam memberikan pelayanan keperawatan.

Peran pendampingan spiritual sebenarnya merupakan kompetensi dari profesi keperawatan. Namun, hal ini dapat dimodifikasi dengan cara melibatkan keluarga dalam pemenuhan kebutuhan spiritual karena keluarga merupakan orang terdekat dengan pasien yang dianggap mampu untuk membantu memenuhi kebutuhan spiritual yang diinginkan oleh pasien. Pemenuhan kebutuhan spiritual seperti membantu pasien dalam mengambilkan wudhu, membawa perlengkapan ibadah yang biasa digunakan, membantu pasien untuk sabar dan ikhlas menghadapai penyakit, dan memberikan dukungan terhadap perubahan postif yang dilakukan oleh pasien.

Melakukan modifikasi lingkungan juga bisa menjadi alternatif tambahan untuk meningkatkan kesadaran dan pemenuhan kebutuhan spiritual. Hal yang dapat dilakukan seperti memmodifikasi ruang rawat inap dengan menampilkan simbol-simbol yang berisi informasi terkait pemenuhan kebutuhan spiritual.

\section{KESIMPULAN}


1. Karakteristik responden sebagian besar berada pada kategori usia dewasa akhir, berjenis kelamin perempuan, kebanyakan responden tidak bekerja, berpendidikan tamatan SMA dan talah memiliki status perkawinan. Responden pada penelititan ini mayoritas terdiagnosa menderita penyakit kanker paudara.

2. Kepuasan pasien penyakit kronis terhadap pemenuhan kebutuhan spiritual selama dirawat di RSUD Arifin Achmad diperoleh hasil bahwa pasien merasa tidak puas dengan pemenuhan kebutuhan spiritual.

\section{SARAN}

1. Bagi RSUD Arifin Achmad Provinsi Riau

Hasil penelitian ini diharapkan mampu memberikan gambaran kebijakan yang harus dievaluasi oleh pelayanan rumah sakit dalam meningkatkan kebijakan pelayanan pada aspek spiritual yang belum optimal pada pemenuhan kebutuhan untuk melakukan praktik ibadah dan menjalin hubungan baik kepada orang lain.

\section{Bagi Institusi Pendidikann STIKes Hang Tuah Pekanbaru}

Hasil penelitian ini diharapkan mampu memberikan gambaran tentang kebutuhan yang diinginkan oleh pasien terkait pemenuhan kebutuhan spiritual. Hendaknya institusi pendidikan mempertimbangkan beberapa hal untuk meningkatkan informasi terkait keperawatan spiritual dengan memberikan materi bahan ajar tentang asuhan keperawatan spiritual secra khusus agar peserta didik mampu memahami dan memberikan pelayanan spiritual secara proesional.

\section{Bagi pasien penyakit kronis}

Diharapkan kepada pasien penyakit kronis untuk tetap memperhatikan dan peka terhadap kebutuhan spirirtual yang dibutuhkan oleh diri sendiri dan orang lain serta yang paling utama adalah hubungan dengan Allah karena aspek spiritual juga memegang peranan penting dalam status kesehatan seseorang.

4. Bagi peneliti selanjutnya

Bagi peneliti selanjutnya diharapkan mampu menjadikan hasil penelitian ini sebagai informasi dasar untuk mengkaji lebih lanjut tentang bagaimana tingkat pengetahuan tenaga kesehatan terkait kebutuhan spiritual dan apa saja upaya yang harus dilakukan untuk meningkatkan kesadaran terhadap pemenuhan kebutuhan spiritual. 


\section{DAFTAR PUSTAKA}

Abuatiq, A. (2015). Spiritual care for critical care patients. International journal of nursing clinic and practices, 2 (128), 1-4. ISSN: 2394-4978.

Asmadi. (2008). Teknik prosedural keperwatan: Konsep dan aplikasi kebutuhan dasar pasien. Jakarta: Salemba Medika.

August. K. J., Sorkin. D. H. (2010). Marital status and gender differences in managing a chronic illness: the function of health-related social control, 71(10): 1831-1838. doi:10.101.

Baldecchino, D. (2015). Spiritual care education of health care professionals. Journal Religions, (6), 594 - 613. ISSN 2077-1444.

Bennett, V., Margo L, T. (2015). Teaching spirituality to student nurses. Journal of nursing education and practice. 5 (2), 26-33. DOI: 10.5430/jnep.v5n2p26.

Centers for Disease Control and Prevention. (2016). Chronic diseases: The leading causes of death and disability in the united States. Diambil pada 11 April, 2017, dari https://www.cdc.gov/chronicdisease/overview/ Centers for disease control and prevention.

Departemen Agama RI. (2008). Al-Qur'an dan terjemahannya. Bandung: Diponegoro.

Dewi, S. R. (2014). Buku ajar keperawatan gerontik. Yogyakarta: Deepublish.

Efendi. F., Makhfudi. (2009). Keperawatan kesehatan komunitas: Teori dan praktik dalam keperawatan. Jakarta: Salemba medika.

Farianita. R. (2016). Faktor-faktor yang berhubungan dengan kepuasan peserta BPJS terhadap pelayanan instalasi rawat jalan di rumah sakit TK.III Bhakti Wira Tamtama Semarang. Jurnal publikasi.

Hamid, A. Y. S. 2008. Bunga rampai asuhan keperawatan kesehatan jiwa. Jakarta: EGC.

Hamid, A. Y. S. 2008. Bunga rampai asuhan keperawatan kesehatan jiwa. Jakarta: EGC. 
Ilhamsyah., Sjattar. E. L., Hadju. V. ( 2013). Hubungan pelaksanaan keperawatan spritual terhadap kepuasan spritual pasien di rumah sakit Ibnu Sina Makassar. Diambil pada 24 Agustus 2017, dari http://file://C:/Users/apple\%20pc/Downloads/ilhamsyah.pdf.

Lestari. I., Safuni. N. (2015). Pemenuhan kebutuhan spiritual pada pasien gagal ginjal kronik di rumah sakit umum Aceh. Diambil pada 23 Agustus 2017, dari http://file://C:/Users/apple\%20pc/Downloads/lestari.pdf.

Noor, A. E. N. (2016). ICU nurse's perceptions and practice of spiritual care at the end of life: implications for policy change. OJIN: The Online Journal of Issues in Nursing, 21(1). diperoleh dari http://www.nursingworld.org/MainMenuCategories/ANAMarketplace/ANAPeriodicals /OJIN/TabelofContents/Vol-21-2016/No1-Jan-2016/Articles-Previous-Topics/ICUNurses-Perceptions-and-Practice-of-Spiritual-Care.html, 161120161857.

Oroh. M. E., Rompas. S., Pondang. L. (2014). Faktor-faktor yang berhubungan dengan tingkat kepuasan pasien rawat inap terhadap pelayanan keperawatan di ruang interna RSUD Noongan. Diambil pada 20 Agustus 2017, dari http://file://C:/Users/apple\%20pc/Downloads/orong.pdf.

Pohan, I. S. (2007). Jaminan mutu layanan kesehatan: Dasar-dasar pengertian dan penerapan. Jakarta: EGC.

Potter, P. A., Perry, A. G. (2010). Fundamental keperawatan: Konsep, proses dan praktik (Edisi 7). Volume 3. Jakarta : EGC.

Prasetiyo. A. C. (2015). Hubungan karakteristis pasien dengan persepsi pasien tentang kualitas pelayanan kesehatandi Puskesmas Blora kabupaten Blora. Diambil pada 20 Agustus 2017, dari http:// file://C:/Users/apple\%20pc/Downloads/Prasetiyo,\%202015.pdf.

Rajinikanth, AM. (2006). Spiritualitty in nursing. New Delhi: Medical Puslishers.

Ristianingsih, D., Septiwi, C., \& Yuniar, I. (2014). Gambaran Motivasi dan Tindakan Keperawatan dalam Pemenuhan Kebutuhan Spiritual Pasien di Ruang ICU PKU Muhammadiyah Gombong. Jurnal IImiah Kesehatan Keperawatan,10:91-99. 
Setiawan. I., Kariasa. I.M. (2013). Tingkat kepuasan pasien terhadap pelayanan perawat di unit gawat darurat rumah sakit haji Jakarta. Diambil pada 20 Agustus 2017, dari http:// file://C:/Users/apple\%20pc/Downloads/ Setiawan\%20\&\% 20Kariasa\%20(2013).pdf.

Stefan. M.M., Redjeki. G.S., Susilo. W.H. (2013). Hubungan karakteristik pasien dengan kepuasan pasien terhadap pelayanan kesehatan di Puskesmas kecamatan Pesanggrahan Jakarta Selatan. Artikel ilmiah publikasi.

Sumarni., Dewi. Y. I., Arneliwati. (2016). Analisis asuhan keperawatan spiritualitas pada pasien kanker payudara. Skripsi yang tidak dipublikasikan.

Tuasikal, M. A. (Januari, 2009). Alasan Wanita Tidak Jadi Pemimpin. Rumaysho. Diperoleh dari https://rumaysho.com/949-alasan-wanita-tidak-pantas-jadi-pemimpin.html. 